\author{
Joanna Zagożdżon-Łyszczarz* \\ Uniwersytet Opolski
}

\title{
Encyklopedyczna wykładnia symboliki orła w twórczości Mikołaja Reja i Marcina Bielskiego
}

\section{Streszczenie:}

Tematem artykułu jest symbolika orła rozpatrywana na tle dawnej tradycji encyklopedycznej. Zestawienie erudycyjnych treści z zakresu historii naturalnej z fragmentami dzieł Mikołaja Reja i Marcina Bielskiego przynosi interesujące spostrzeżenia. Powszechnie wiadomo, że uniwersalny charakter symboliki orła jako emblematu władzy w kulturze staropolskiej zajmował wyjątkowe miejsce w heraldycznym zwierzyńcu. Jednakże, alegoryczne wykładnie związane z motywem tego królewskiego ptaka w utworach naszych pisarzy okazują się wykraczać poza tradycyjnie przyjęte interpretacje. Wydaje się bowiem, że symbol orła w poetyckim ujęciu Reja i Bielskiego stanowił przede wszystkim emblemat ptaka niebieskiego, co miało stanowić zapowiedź głębokiej przemiany duchowej całego naszego narodu. Wiele także wskazuje na to, że akwilarna symbolika stanowiła niezwykle nośny element konstrukcyjny w dawnych dziełach encyklopedycznych.

Słowa-klucze: symbol orła, księga natury, bestiariusz, fizjologus, Mikołaj Rej, Marcin Bielski.

Joanna Zagożdżon-Łyszczarz - doktor nauk humanistycznych, adiunkt Uniwersytetu Opolskiego w Zakładzie Literatury Staropolskiej i Oświeceniowej. Autorka książki Sen w Literaturze średniowiecznej i renesansowej, Opole 2002. 


\section{Encyclopaedic interpretation of eagle symbolism in works by Mikołaj Rej and Marcin Bielski}

\section{Summary:}

The article focuses on eagle symbolism in the context of an old encyclopaedic tradition. A combination of erudite contents within natural history with fragments of Mikołaj Rej's and Marcin Bielski's works leads to interesting observations. It is common knowledge that a universal character of the symbolism of an eagle as an emblem of power in Old Polish culture had an exceptional place in heraldic bestiary. Nonetheless, algorithmic interpretations connected with a motif of this royal bird in the works of our writers seem to go beyond traditionally assumed interpretations. Here, it appears that the symbol of an eagle in poetic rhetoric of Rej and Bielski primarily constituted an emblem of a celestial bird, which was to foretell deep spiritual transformation of our nation. There are as well many arguments suggesting that aquilar symbolism constituted an exceptionally strong construction element in old encyclopaedic works.

Key words: eagle symbolism, book of nature, bestiary, physiologus.

Idea księgi natury była honorowana przez najwyższe akademickie autorytety tak w średniowieczu, jak i w dobie Renesansu ${ }^{1}$. Przyroda uchodziła od zawsze za największą nauczycielkę i duchową przewodniczkę. Nieprzypadkowo też dwa pojęcia: naturalista i moralista, występowały niegdyś zamiennie jako synonimy². Podwójna natura człowieka postrzegana w kategoriach istoty duchowo-cielesnej właśnie w obrazie ptaka znajdowała swój najpełniejszy wyraz. W dawnej tradycji encyklopedycz-

1 J. V. Fleming, Natura Lachrymosa, [w:] Man and Nature in the Middle Ages, ed. by S. J. Ridyard and R. G. Benson, Sewanee 1995, s. 17.

2 Tamże, s. 23. 
nej świat uznawany był za ,uporządkowany zbiór stworzeń [...]"3. Poznanie uniwersum polegało zatem nie tyle „na zliczeniu wszystkich znajdujących się w nim dzieł, ile przede wszystkim na szukaniu porządku, w jaki włączyła je mądrość Boża"4. Najistotniejsze informacje czerpano z Księgi Genesis, gdzie geniusz Stwórcy wcielił królestwo latających istot w dzieło dnia piątego:

Rzekł Bóg po tym: »Niech wody hojnie zrodzą płód mający duszę żywą. A ptastwo niech lata nad ziemią pod rozpostrzeniem niebieskim!« (Gen. 1, 20) .

Skoro alegoryczna interpretacja ojców Kościoła wskazywała na umysł czy serce człowieka jako na „sklepienie nieba”, to dziwić nie może przeciwstawianie poziomej natury zwierzęcej podniebnym lotom ptaków. Wszak miały one „od spraw ziemskich dążyć ku sprawom najwyższym”. Zarówno Rej, jak i Bielski, posługiwali się niezwykle żywotną klasyfikacją zwierząt wprowadzoną przez encyklopedystę Izydora z Sewilli (VII w.), gdzie w oddzielną kategorię ptaków włączano praktycznie wszystko, co potrafiło wznieść się w powietrze. Znalazły się więc w niej także owady, jak pszczoły, motyle, niektóre robaki, bajeczne zwierzęta czy uskrzydlone ssaki-nietoperze. Pośród latających stworzeń orzeł (łac. aquila) uchodził za twór najdoskonalszy ze wszystkich. Arystoteles wspominał o odwadze tego boskiego ptaka: „Ma on szybki lot i harmonijne upierzenie. Jest bez zazdrości i bez bojaźni"’. Orzeł był niekwestionowanym panem powietrza. Okrzyknięto go więc królem ptaków i ptakiem królów ${ }^{8}$.

3 J.-M. Parent, La doctrine de la création dans lécole de Chartres, Paris-Ottawa 1938, s. 146.

4 N. Max Wildiers, Obraz świata a teologia. Od średniowiecza do dzisiaj, przeł. J. Doktór, Warszawa 1985, s. 19.

5 Pierwsze Księgi Mojżeszowe, które zowa językiem greckim Genesis a po polsku Początkiem albo rodzajem, [w:] Biblia święta to jest Księgi Starego i Nowego Zakonu wtasnie $z$ żydowskiego, greckiego i łacińskiego nowo na polski z pilnościa $i$ wiernie wyłożone. Transkrypcję oraz kolacjonowanie tekstu Biblii Brzeskiej [Brześć 1563] [...], edycja P. Krolikowski, Clifton, New Jersey-Kraków 2003, s. 1.

6 Orygenes, Homilie o Księgach Rodzaju, Wyjścia, Kapłańskiej, przeł. i oprac. S. Kalinkowski, wstęp E. Stanula, Warszawa 1984, s. 29.

7 Arystoteles, Zoologia (Historia animalium), przeł., wstępem, komentarzem i skorowidzem opatrzył P. Siwek, Warszawa 1982, s. 399. 
W wielu cywilizacjach stanowił symbol solarny, kojarzony z ogniem, światłem, oświeceniem i wysokością ${ }^{9}$. Pełnił często zarówno funkcję niebieskiego posłańca, jak również przewodnika dusz - psychoforosa ${ }^{10}$. Przylgnął także do niego ,przydomek aquila victrix - orzeł zwycięski, do czego miały się przyczynić między innymi rzymskie legiony"11. Ścisły związek ptaków z boskimi mocami sprawił, iż wróżbom z ich lotu przypisywano pomyślność ${ }^{12}$. Bielski w swojej Kronice wszytkiego świata przytoczył wiele takich anegdot, jak choćby historię o orle, który porwał Tarquiniusowi czapkę, wróżąc mu koronę: „wzleciał z nią wzgórę i spuścił zasię prosto na głowę”"13.

W kulturze chrześcijańskiej orzeł łączył tradycje związane z problematyką eschatologiczną. Księga Przypowieści Salomonowych wymienia pośród trzech skrytych rzeczy jedną, którą jest „droga orła na powietrzu” (Prz. 30, 19) ${ }^{14}$. O jego niezwykłym sposobie latania pisał także Arystoteles w Historia animalium. Ptak ten bowiem unosząc się, „nie schodzi w pionowej linii na ziemię, lecz stopniowo zatacza coraz ciaśniejsze koła"15. Rej - podobnie jak Bielski - podzielał przekonanie wspólne dawnym encyklopedystom, że „wszystkie stworzenia świata są dla nas niby księga, obraz i lustro"16. Nasi pisarze wierzyli, zgodnie z refleksją św. Augustyna, że znajomość symboliki natury może okazać się zbawienna. Dlatego wiedzę dotyczącą ptaków, prócz Biblii, czerpali z przeróżnych

8 D. Forstner, Świat symboliki chrześcijańskiej, przeł. i oprac. W. Zakrzewska, P. Pachciarek, R. Turzyński, wybór il. i komentarz T. Łozińska, Warszawa 1990, s. 241.

9 S. Kobielus, Bestiarium chrześcijańskie. Zwierzęta $w$ symbolice i interpretacji. Starożytność i średniowiecze, Kraków 2002, s. 232.

10 B. Iwaszkiewicz, Problematyka symboliki motywu orła $w$ sztuce wczesnochrześcijańskiej, „Roczniki Teologiczno-Kanoniczne” 1974, t. XXI, z. 4, s 207.

11 Tamże, s. 233.

12 Arystoteles, dz. cyt., s. 399.

13 M. Bielski, Kronika to jest historia Świata na sześć wieków a cztery monarchie rozdzielona $z$ rozmaitych historyków tak $w$ świętym piśmie krześcijańskim, żydowskim jako i pogańskim wybierana i na polski język wypisana dostateczniej niż pierwej z przydanim wiele rzeczy nowych: Od poczatku świata aż do tego roku, który sie pisze 1564. Figurami ochędożnymi i wtasnymi, przedruk metodą fotooffsetową, Warszawa 1976, list 102v.

14 Księgi Przypowieści Salomonowych, [w:] Biblia Brzeska..., dz. cyt., s. 602.

15 Arystoteles, dz. cyt., s. 401.

16 Przypisuje się te słowa Allanowi z Lille. Cyt. za: A. Guriewicz, Kategorie kultury średniowiecznej, przeł. J. Dancygier, Warszawa 1976, s. 62. 
encyklopedycznych opracowań w rodzaju fizjologusów, bestiariuszy, czy naturalnych historii. Jak zaznaczył Rej w Wizerunku:

Czego acz z przyrodzenia czasem wiele znajdzie, Ale bezpieczniejszy krok ku onej cnej prawdzie, Kto ją umie rozeznać: jednę część z nauki, A drugą z przyrodzenia, nie ledać to sztuki ${ }^{17}$.

Uważna obserwacja rozmaitych kształtów stworzeń w obrębie widowiska tego świata pozwalała na poznanie doskonałości dzieł Stwórcy, jak również dowiedzenie się czegoś więcej o samym sobie. Niezwykła różnorodność królestwa ptaków, o czym rozpisywał się Albert Wielki, prowokowała do szukania licznych podobieństw między nimi a ludźmi. W kulturze chrześcijańskiej „spuścizną po antycznej metaforyce stał się wizerunek skrzydlatego stworzenia jako duszy ulatującej do Boga"18. Ptaki symbolizowały siłę, która przydawała człowiekowi nadprzyrodzonego rozumu i rozsądku. Św. Hieronim wzywał wszystkich wiernych, aby „wzlatywali skrzydłami miłości i używali ich jak wioseł [...], aby każdy wzniósł duszę leżącą na ziemi i skierował ją do tego, co jest wzniosłe; pobudził orła, który jest w nas [...]"19.

Jednakże tym, co wyróżniało orła - jak pisał Izydor z Sewilli - był jego niezwykle bystry wzrok (łac. acumen oculorum) ${ }^{20}$. Podobnie Albert Wielki w De animalibus twierdził, że aquila jest tak nazwany od swego ostrego i przenikliwego wzroku (łac. acumen). Posiadał bowiem trzy cechy, które świadczyły o niezwykłym wyostrzeniu jego zmysłów, tj. widzenie, gniewny temperament oraz myśliwskie akcesoria, czyli szpony

17 M. Rej, Wizerunk własny żywota człowieka poczciwego. Cz. I: Fototypia i transkrypcja tekstu, oprac. W. Kuraszkiewicz, Wrocław 1971, s. 77.

18 L. Impelluso, Natura i jej symbole. Rośliny i zwierzęta, przeł. H. Cieśla, Warszawa 2006, s. 288.

19 Św. Ambroży, Wybór pism. O pokucie. O ucieczce od tego świata. O dobrach przynoszonych przez śmierć, przeł. W. Szołdrski, wstęp C. A. Guryn, oprac. C. A. Guryn i E. Stanula, Warszawa 1971, s. 141.

20 Etymologies of Isidore of Seville, transl. S. A. Barney, W. J. Lewis, J. A. Beach, O. Berghof, New York 2006, s. 264. 
i dziób. Orzeł rośnie w siłę, dzięki bystrości spojrzenia, „[...] nazywany jest także «szlachetnym orłem», [...] jakby był herosem ptaków"21. Trzeba przyznać, iż część tej encyklopedycznej notatki na temat orła można znaleźć w XVI-wiecznym zielniku autorstwa Falimirza pt. O ziołach $i$ mocy ich:

Orzeł między ptaki jest najmężniejszy i najświebodniejszy. Przeto też królem ptasim jest wezwan. Si[e]dli się na drzewie barzo wysokiem, na które żadna szkodliwa bestia wleźć nie może. Dzieci swoich barzo broni, a nigdy nie opuszcza, aże kiedy samy się bronić mogą, a gdyby mu je kto chciał zebrać, dziwną śmiałością broni. Wzrok ma bardzo ostry tak iże też w słońce śmiele może wejrzeć. Na co dzieci swoje z młodu zwyczai, oczyma je ku Słończu nogą za szyje podnosząc. A które by się patrzenia broniło, oczy odwracając. Tedy je z gniazda wyrzuca jako nie godne rodu swego 22 .

Rej już we wstępie Postylli mocno wyeksponował uniwersalny charakter symboliki orła jako emblematu władzy, który w naszej kulturze zajmował wyjątkowe miejsce $\mathrm{w}$ heraldycznym zwierzyńcu. Pierwszy wiersz Ku Orłowi iego Królewskiej Miłości stanowił jakby apostrofę skierowaną do Boga, aby miał w opiece tego ptaka, który jest symbolem ideału władcy: „Jedno rozmiłuj Pana swego/ Szczyrej prawdy świętej wolej jego"23. Napisany został w tonie modlitewno-proszalnym, gdzie pojawiło się pragnienie, aby orzeł-król pozostał wierny najważniejszym chrześcijańskim wartościom. Miał on więc stać się ich najbardziej zaufanym strażnikiem. Stąd też wynikało życzenie: „Że nie zelżysz ni w czym zacności swej" 24 . Nie chodziło tu zatem jedynie o władzę ziemską, ale o coś znaczenie ważniejszego.

W drugim utworze na orła Jego królewskiej Mości z Postylli zawarł Rej wszystkie metaforyczne wątki dotyczące tego ptaka, [...], stopniowo

21 Albertus Magnus, On Animals. A Medieval Summa Zoologica, vol. II, transl. and annotated by K. F. Kitchell Jr. \& I. M. Resnick, London 1999, s. 1547.

22 S. Falimirz, O ziołach i mocy ich [...], wyd. F. Ungler, Kraków 1534, list 17r.

23 M. Rej, Postylla, cz. II (nauk. opieka nad fototypią W. Floryan), red. M. R. Mayenowa, Bibl. Pisarzów Polskich ser. B, nr 14, Wrocław 1965, list 1v.

24 Tamże. 
rozwijane w późniejszej twórczości. Wiadomo, że wiersz ten stanowił „przejrzystą apostrofę do króla Zygmunta Augusta, którego zwolennicy reformacji pragnęli pozyskać dla swojej sprawy"25. Jednak już sam tytuł: İ் Orzet iest własnie przywłaszczon za herb a za klenot krolom, książętom, a przełożonym swiata tego sugerował, że tekst kierowany był nie tyle do jednego odbiorcy, ile do całego stanu. Za pośrednictwem tego królewskiego ptaka autor starał się przedstawić najważniejsze problemy ówczesnej Polski. Okazało się to możliwe:

Bo ten ptak nad ine ptaki,

Swej zacności dziwne znaki,

Nad przyrodzenie sprawuje,

A znaczenie to okazuje,

Że jest z królmi królem²6,

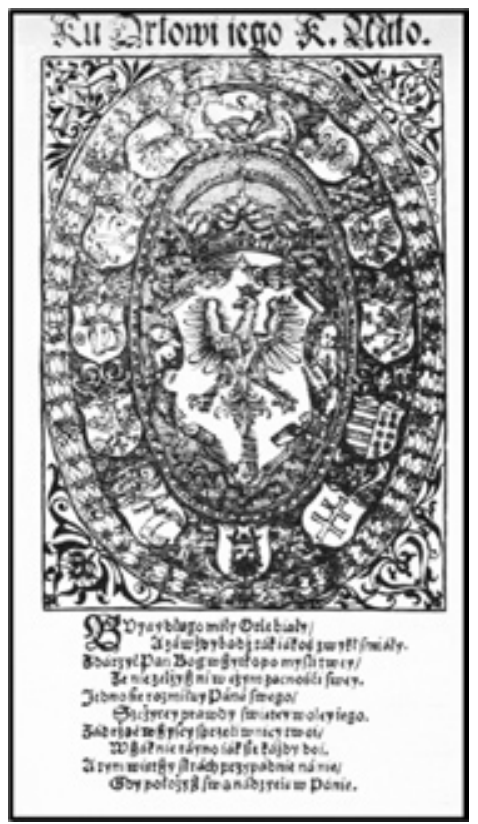

Orzeł, Postylla Mikołaja Reja

25 K. Górski, J. Klimaszewska, W. Kuraszkiewicz, Objaśnienia, [w:] M. Rej, Postylla, cz. I, oprac. K. Górski i W. Kuraszkiewicz, Wrocław 1965, s. 269.

26 M. Rej, Postylla, cz. II, dz. cyt., list 2r. 
Dalsza charakterystyka orła wyliczała jego liczne zalety, które składały się na doskonały wzór człowieka poczciwego. Poeta zobowiązywał do szczytnego naśladownictwa wszystkich noszących ten klejnot w herbie. Pierwszą cnotą orła była sprawiedliwość:

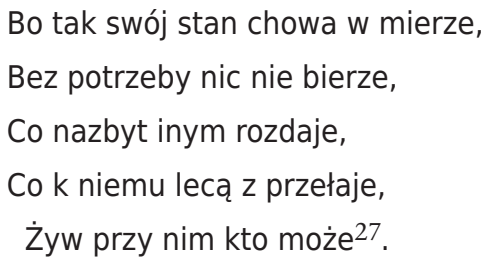

Faktycznie, zarówno w bestiariuszach, historiach naturalnych czy w De animalibus Alberta Wielkiego podkreślano wielkoduszność króla królów, z jaką dzielił się on swoją zdobyczą z innymi ptakami ${ }^{28}$. Rej zamilczał co prawda informację o gniewliwości i okrucieństwie, z jakich słynął orzeł. Podkreślał natomiast fakt, iż ptak ten zawsze wspiera we wszystkim skrzydlatych współbraci. Okszyc wykorzystał ważne w kulturze dawnej Polski pojęcie „stryja” jako surowego opiekuna ${ }^{29}$. Swoistą cechę szlacheckiego obyczaju stanowiło bowiem przekonanie o pewnej solidarności i łączności rodowej. Stryjcowie byli to potomkowie jednego przodka w różnych stopniach pokrewieństwa. Stanowili więc wielką rodzinę polską ze wspólnym herbem ${ }^{30}$. Rej wyraźnie podkreślił zarówno szlachetny charakter pozostałych polskich dostojników i obywateli, jak również obowiązki wynikające z ich wysokiej pozycji społecznej:

Także też Stryj ma być.

Latać z myślą pod obłoki,

Przepatrując świat szyroki,

27 Tamże.

28 Albertus Magnus, dz. cyt., vol. II, s. 1550.

29 K. Górski, J. Klimaszewska, W. Kuraszkiewicz, Objaśnienia, [w:] M. Rej, Postylla, cz. I, dz. cyt., s. 269.

30 Z. Gloger, Encyklopedia staropolska ilustrowana, t. IV, wstęp J. Krzyżanowski, Warszawa 1989, s. 65. 
Z wszytki przypadki na nim,

Swym poważnym rozeznaniem,

A co lepszego strzedz ${ }^{31}$.

Następna część utworu dotyczyła konieczności wprowadzenia zmian w polskim życiu społecznym, politycznym i gospodarczym. Jednakże sfera symboliki odrodzenia się orła, do jakiej została odniesiona treść wiersza, sprawiła, że całość wypada rozumieć także w kategoriach głębokiej przemiany duchowej całego naszego narodu:

\footnotetext{
Zwyczaje stare odmienić,

Jeśli ich trzeba poprawić,

Odnowić nos i paznogcie,

Na ony zuchwałe nogcie,

Co więc drugie drapią 32 .
}

W Fizjologusie (ok. II w.), którego popularność w dawnych wiekach można porównać - według Edwarda P. Evansa - jedynie z Pismem Świętym $^{33}$, pojawiła się informacja o możliwości cudownej odnowy umierającego orła. Oto bowiem:

[...] gdy ptak ten starzeje, słabną jego oczy i skrzydła i zaczyna niedowidzieć. Cóż więc czyni? Szuka źródła czystej wody i wzbija się w słoneczne niebo, i spala swoje stare skrzydła i ciemność swoich oczu. Potem obniża się w dół ku źródłu i zanurzywszy się w nim trzy razy, odradza się i młodnieje ${ }^{34}$.

Powszechność tego motywu w ówczesnych opracowaniach encyklopedycznych musiała być naprawdę duża, czego najlepszym dowodem jest fragment zaczerpnięty z innego staropolskiego Herbarza Marcina Siennika, który stanowi przekład ksiąg Alexego Pedemontana z autorskimi

31 M. Rej, Postylla, cz. II, dz. cyt., list 2v.

32 Tamże.

33 Cyt. za: tamże.

34 Fizjolog, przekł., wstęp i przyp. K. Jażdżewska, Warszawa 2003, s. 28. 


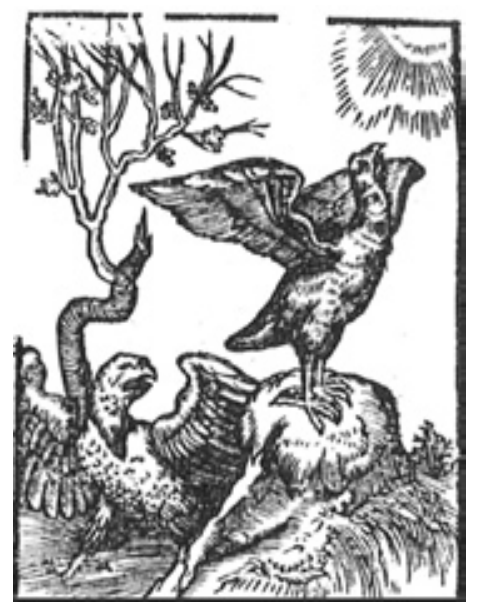

Orzeł, M. Siennik, Herbarz to jest ziół tutecznych, postronnych i zamorskich opisanie [...] (1568)

adnotacjami translatora. Opis metamorfozy orła zamieszczony w tym zielniku przypomina słowa Alberta Wielkiego z De animalibus:

Gdy sie już orzeł starzeje, tak iż patrzeć nie może tedy co najwyższej pod obłoki wzlata a gorącością słoneczną sobie oczy wyczyścia, potym zlatując nagle, w wodzie co najzimniejszej sie zanarza, zatym na gniazdo leci miedzy dzieci swe dorosłe, także leży jakoby w gorącce, w tymże sie poci aż z niego wszystko pierze stare opada, gdzież więc dzieci jego żywią go aż zasie moc weźmie, a w tym zasie odmłodnieje [... $]^{35}$.

Niniejsze exemplum Marcin Siennik skwitował uwagą: „nie każdy temu [zdarzeniu] wierzyć może”, podczas gdy sam Albert Wielki odniósł się do przytoczonej deskrypcji z większą dozą ostrożności. Zapisał więc: „,nie wiem, co powiedzieć na to, z wyjątkiem tego, że cudów natury jest wiele"36.

Do niezwykłych wyobrażeń związanych z odrodzeniem orła nawiązuje też fragment Psalmu 103 z Psałterza Dawidów, którego parafrazy dokonał Rej:

35 M. Siennik, Herbarz to jest ziót tutecznych, postronnych i zamorskich opisanie [...], Kraków (drukarnia Szarffenberga) 1568, list 290-291; zob. Albertus Magnus, dz. cyt., vol. II, s. 1547-1553.

36 Albertus Magnus, dz. cyt., vol. 2, s. 1550. 
[Bóg] odnawia często zmazy zastarzałości twoich prawie odmładzając cię jako orła, gdy przed starością zmietuje kość z nosa twego, a ona mu zasie wyrasta ${ }^{37}$.

Według innej uczonej wersji bestiariuszowej: „[...] krzywizna dzioba starego orła stawała się tak znaczna, że z trudnością przyjmował pożywienie i opadał z sił. Wtedy uderzał dziobem o skałę i odłamywał jego koniec; znów mógł jeść i odzyskiwał nowe siły"38. Interpretowano ten fragment alegorycznie, jako zapowiedź ponownych narodzin „duchowego człowieka wewnętrznego”, dokonanych na skale słowa Bożego: „odrzuć stare szaty diabła i wdziej nowe, stworzone wedle Boga"39. Jak Orzeł odradzał się ku nieśmiertelności, tak my do życia wiecznego (2 Kor. 4, 16) ${ }^{40}$. Nawet sceptyczny Erazm z Rotterdamu wspominał o tej cudownej zdolności orła w Adagiach: ,jego boskie pochodzenie sprawiało, iż jako jedyny spośród ziemskich stworzeń potrafił znieść oślepiające światło"41. Orzeł stał się więc inkarnacją wszelkich cnót, które na podobieństwo duchowego przewodnika zaprowadzić miały szlachetną jednostkę do życia wiecznego.

Motyw orła znalazł rozwinięcie w wizji Ezechiela (Proroc. Ez. 1, 1-14), jak również w Apokalipsie św. Jana (Ap. 4, 6-8). Grzegorz Wielki w Moraliach, a za nim Hugon z Folieto w swoim bestiariuszowym Aviarium odnotowali, że starotestamentowy prorok widział w obrazie czterech zwierząt z boskiego rydwanu zapowiedź czterech Ewangelistów ${ }^{42}$. Rej nieco inaczej interpretował te fragmenty Biblii. W Apocalypsis (Roz-

37 M. Rej, Psalterz Dawidow / ktory snadz iest prawy fundament / wssytkiego pisma krzesćyjańskiego / teraz nowo prawie na Polski ięzyk przełożon [...], [Kraków, Mac. Szarfenberg? ok. 1546, list 150r.

38 D. Forstner, dz. cyt., s. 241.

39 Fizjolog, dz. cyt., s. 28.

40 List Wtóry do Koryntów Pawła świętego, [w:] Biblia Brzeska..., dz. cyt., s. 1037: („,...] ale choć też nasz zwierzchni człowiek zepsowan bywa, przedsię wnętrzny człowiek odnawia się na każdy dzień”).

41 Erazm z Rotterdamu, Adagia (wybór), przeł. i oprac. M. Cytowska, BN II, nr 172, Wrocław 1973, s. 253.

42 Zob. Św. Grzegorz, Moralia. Komentarz do Ksiegi Hioba. T. 6: Księgi XXVIII-XXXII, red. nauk. L. Nieścior, przeł. A. Wilczyński, oprac. i korekta przekł. E. Buszewicz, Kraków 2016, s. 330 i n. oraz Hugon z Folieto, Aviarium, [w:] Fizjologi i Aviarium. Średniowieczne traktaty o symbolice zwierząt, red. E. Przybył, przeł. i oprac. S. Kobielus, Kraków 2005, s. 157. 
prawa XXIV), gdzie opisał „dziwny majestat Jana świętego”, przywołał wizję czterech istot z wizji Ezechiela: „A pierwsze zwirzę podobne było ku lwowi, a drugie zwirzę podobne było ku wołowi, trzecie zwirzę miało twarz podobną człowieczej, a czwarte zwirzę podobne ku orłowi latającemu $[. .] "$.43 . Odmiennie jednak niż zastana tradycja wyłożył znaczenie tych bestii:

Czworo zwierząt możemy rozumieć za cztery stany rozlicznych ludzi na ziemi. Bo są mocarze tego świata jako Iwi borzący w możnościach swoich. Są też ludzie prości ni ocz nie dbający, tylko w prostotach swoich jako wołowie używający tego świata mizernego. Są drudzy jako orłowie latający z wyniosłymi rozumy naukami i bystrościami swoimi. Są też drudzy już pomierni a w prostocie swej a w szczyrości prawej używając i żywotów swoich i wszystkich spraw swoich. A ci wżdy są podobni niejako ku człowiekowi. Bo acz tę figurę niektorzy czterzem Ewanjelistom przypisowali, ale jeszcze na ten czas Ewanjelistowie niektórzy żywi na świecie byli ${ }^{44}$.

Tę interpretację czterech zwierząt postrzeganych w kategoriach czterech różnych inteligencji niebieskich Rej przejął prawdopodobnie z pism któregoś z Ojców Kościoła. Niezależnie jednak od typu uzasadnienia związku czterech boskich istot z Ewangelistami, figura Orła kojarzona była zawsze z niebem oraz „spływającą na Kościół łaską Ducha Św."

Chociaż Okszyc nie połączył bezpośrednio obrazu orła ze świętym Janem, to jego alegoryczna wykładnia niniejszego motywu pokrywała się z refleksją św. Grzegorza. Według niej, orzeł stanowił Chrystusowy symbol „wnikliwej wiedzy świętych i ich wzniosłej kontemplacji”46. Wypowiedź naszego pisarza pozostawała też $\mathrm{w}$ zgodzie $\mathrm{z}$ bestiariuszowymi wykładniami dotyczącymi tego królewskiego ptaka:

43 M. Rej, Apocalypsis, pod red. W. Kriegseisena, oprac. M. M. Kacprzak, S. Kawczyński, J. Maciuszko, I. Winiarska, Warszawa 2005, list 48v.

44 Tamże, list 49v-50r. oraz list 131v.

45 D. Forstner, dz. cyt., s. 325.

46 Św. Grzegorz, dz. cyt., s. 331. 
[...] który wznosząc się, opuścił ziemię, ponieważ w widzeniu, przez subtelną umiejętność rozróżniania, przeniknął wewnętrzne tajemnice Słowa. Podobnie ci, którzy od tej chwili porzucą w umyśle sprawy ziemskie, z Janem przez kontemplację wzniosą się na wzór orła do rzeczy niebieskich ${ }^{47}$.

Rej w Apocalypsis (Rozprawa XXXIV) przytoczył zbliżoną opinię, gdzie symbol orła uznał za pokrewny aniołom, które posiadają wgląd w nadchodzace wydarzenia:

[...] widział orła lecącego, który jest wzroku ostrego a z daleka przepatruje rzeczy. Ale orzeł li Anjoł li, tedy to nam znamionuje opatrzność, wiadomość, i z dawna przejrzenie wszytkich rzeczy Pana naszego, które sie miały dziać i dziś i na potym na niebie i na ziemi ${ }^{48}$.

W tym kontekście analizowany fragment wiersza Reja ze wstępu do Postylli na orła Jego Królewskiej Mości nabiera głębszego, bo wręcz mistycznego znaczenia. Mowa tu o konieczności odnowy obyczajów polskich stanów („Odnowić nosy i paznogcie”), aby móc stanąć do walki z łotrostwem tego świata („Na ony zuchwałe nogcie/ Co więc drugie drapią"49). Okszyc w tych zabiegach zmierzających do poprawy swojej i cudzej natury zalecał $\mathrm{w}$ pierwszej kolejności łagodniejsze środki perswazji: „Przestraszyć ich pierwej głosem”. Jeśli to nie poskutkuje, to radził dopiero zadziałać siłą „Potym paznogty i nosem”, czyli szponami i dziobem. Wszak orzeł słynął z odwagi, z jaką bronił swojego gniazda. Zgodnie z tymi przekonaniami Rej dowodził:
Nie srożyć się bez przyczyny
Lecz mocno bronić dziedziny
Jako Orzeł gniazda krzywdy
W to się nie da dotknąć nigdy 50 .

47 Hugon z Folieto, Aviarium, dz. cyt., s. 157.

48 M. Rej, Apocalypsis, dz. cyt., list 75v.

49 Tegoż, Postylla, cz. II, dz. cyt., list 2v.

50 Tamże. 
Kiedy jednak nasz poeta wspominał o bitewnych zmaganiach, to skierował wyobraźnię odbiorcy w stronę całej społeczności, tj. bezpośrednio w obszar sakralnej przestrzeni, jaką stanowiło rodzime gniazdo. $\mathrm{W}$ bestiariuszowych opracowaniach było ono znakiem nadziei i bezpieczeństwa w wierze ${ }^{51}$. Rej chętnie w swojej twórczości nawiązywał do niniejszego motywu. W Żywocie człowieka poczciwego tak scharakteryzował to święte miejsce:

Bo gdzie prawda zawije gniazdo swe, już i sprawiedliwość, już i stałość, już i pomierność, już i roztropność i insze wszytki cnoty nie lza, jedno sie przy niej osadzić muszą 52 .

Podobnie przedstawił tę myśl w Wizerunku:

Bowiem prawe ślachectwo jest jakaś moc dziwna

A każdej marnej sprawie na wszytkim sprzeciwna, Która by bujny orzeł po powietrzu lata,

A nigdy się niesłusznych przypadkow nie chwata.

A kogo tym obdarzą z niebieskiego grodu, Już ten sławy poprawi, poślachci i rodu ${ }^{53}$.

Stopniowo wyłonił się z analizowanego przez nas wiersza Reja archetypiczny obraz ethosu polskiej szlachty. „Urodzonej w miejscu ojczystym", zwanej gniazdem, będącej dziećmi Natury, która wraz z nią uczestniczy w misterium odradzania się życia" ${ }^{54}$. Rej tę głęboką myśl zamknął w kilku wersach:

51 S. Kobielus, Bestiarium chrześcijańskie. Zwierzęta $w$ symbolice i interpretacji. Starożytność $i$ średniowiecze, Warszawa 2002, s. 371.

52 M. Rey z Nagłowic, Żywot człowieka poczciwego, t. 1, [w:] tegoż, Źwierciadło albo kształt, $w$ którym każdy stan snadnie sie może swym sprawam, jako we źwierciedle, przypatrzyć, t. 1-2, wyd. J. Czubek i J. Łoś, wstęp I. Chrzanowski, Kraków 1914, s. 237.

53 Tegoż, Wizerunk własny żywota człowieka poczciwego, cz. II, oprac. W. Kuraszkiewicz, Wrocław 1971, s. 437.

54 A. Nowicka-Jeżowa, Barok polski między Europa i Sarmacja. Cz. I: Profile i zarysy catości, Warszawa 2009-2011, s. 247. 
A dobre do siebie ciągnąć,

A przy swym je gnieździe lągnąć,

A od inych bronić55.

Grzegorz Wielki rozpostarł w Moraliach wizję siedziby królewskiego ptaka od ziemi do samego nieba: „Orzeł buduje gniazdo nadziei na wysokościach [...]. Wysoko ma swoje gniazdo, ponieważ swoje myśli utwierdza w niebiosach" 56 . Nobilitacja wynikająca z możliwości przebywania w orlim gnieździe zobowiązywała jego mieszkańców do nieustannej pracy nad sobą. To przyrodzone orłom szlachectwo poddawane było - według encyklopedystów - ważnej próbie. Chodziło o zastrzeżoną tylko dla tych ptaków umiejętność patrzenia prosto w słońce. Dlatego miały one w zwyczaju sprawdzanie jakości swoich piskląt. Kiedy młode nie mogły znieść jaskrawego blasku słonecznego, rodzice wyrzucali je z gniazda. Powód tego postępowania wyjawił Ambroży w Hexaemeronie. Oto bowiem „królewskie stanowisko, jakie posiadał [orzeł] wśród ptaków, nie mogło ucierpieć z powodu niezaradności któregoś z potomków"57. Ten zwyczaj musiał mieć w pamięci Rej, kiedy w utworze na orła Jego Królewskiej Mości zwracał się do dygnitarzy i panów braci:

\footnotetext{
A tak wy zacni stanowie, Gdzieżeście jako Orłowie, Są tu na świat wystawieni, Niechże sie w was nic nie mieni, Co Strijom przystoi. Uważajcie tak swe stany, Niech was prawe Orły znamy ${ }^{58}$.
}

55 M. Rej, Żywot człowieka poczciwego, dz. cyt., t. 1, s. 237.

56 Grzegorz Wielki, dz. cyt., s. 332.

57 Św. Ambroży, Hexaemeron, przeł. W. Szołdrski, opatrzył wstępem A. Bogucki, oprac. W. Myszor, Warszawa 1969, s. 173-174.

58 M. Rej, Postylla, cz. II, dz. cyt., list 2v. 
Ten bezduszny postępek nie wynikał z ich okrucieństwa, ale $\mathrm{z}$ chęci upewnienia się, czy pisklęta są rzeczywiście potomstwem orłów, ponieważ rodzice nie wyrzucali swoich własnych dzieci, lecz jedynie cudze.

Albert Wielki w De animalibus poddał w wątpliwość jakąkolwiek możliwość podmiany orlego potomstwa. Tłumaczył to zarówno niedostępnością ich siedliska, jak również tym, „że żaden rodzaj ptaków nie miałby takiej śmiałości, żeby zbliżyć się do orlego gniazda"59. W innej wersji bestiariuszowego komentarza, bliższej poglądom Okszyca, ta krwawa próba miała na celu wyeliminowanie jednostek nie zasługujących na zaszczytne miano tego najszlachetniejszego gatunku spośród ptaków. Encyklopedysta Izydor z Sewilli w Etymologiach zaznaczył: „panuje opinia, że orzeł nie odwraca wzroku od słońca; wystawia swoje pisklęta uchwycone szponami na promienie słoneczne i te, które nie odwracają wzroku, zachowuje jako wartościowe, natomiast te, które chowają wzrok, odrzuca jako nieudane" 60 . Św. Ambroży w komentarzu do Ewangelii według św. Mateusza porównał do orłów dusze wszystkich cnotliwych ludzi ${ }^{61}$. Rej w Żywocie człowieka poczciwego otwarcie wypowiedział się na temat kwestii odpowiedzialności „synów orłowych”:

A jeśliżeś ślachcic, żyw ‘ze poczciwie, jako na ślachcica przysłusze. Boć to samo przezwisko szlachcic zawżdy ten dekret na cię feruje, abyś sie zachował, jako ślachcic, aby cie nikt ni w czym winować, ani cie nietrefnie, z jakich twoich nieforemnych przypadków strofować nie mógł [... $]^{62}$.

Fizjologus powoływał się na autorytet Mojżesza, który chwalił orła za to, że strzeże swojego gniazda i chroni swoje pisklęta ${ }^{63}$. Stąd popularny

59 Albertus Magnus, dz. cyt., vol. II, s. 1548.

60 Etymologies of Isidore of Seville, dz. cyt., s. 264.

61 S. Kobielus, Bestiarium chrześcijańskie..., dz. cyt., s. 235. Do tego motywu nawiązywały podobizny na polskich monetach z XII- wieku, które przedstawiały orła atakującego węża, zob. R. Kiersnowski, Symbol ptaka, [w:] Imagines Potestatis. Rytuały, symbole $i$ konteksty fabularne władzy zwierzchniej. Polska X-XV w., pod red. J. Banaszkiewicza, Warszawa 1994, s. 107.

62 M. Rej, Żywot człowieka poczciwego, dz. cyt., s. 158.

63 Fizjolog, dz. cyt., s. 82. 
w dawnej literaturze stał się motyw walki orłów ze smokami lub wężami. Bestiariuszowa tradycja zaświadczała, że ptaki te:

odpędzają wszelkiego gada, nas zaś zachowują w słusznej wierze, abyśmy strzegli się, słuchali [boskich] przykazań i przebywali w Kościele niczym w gnieździe ${ }^{64}$.

Orzeł był więc strażnikiem zarówno swojego gniazda, jak również najcenniejszych duchowych wartości. Kiedy więc Rej przyrównywał ludzki świat do „ptaszego pola”65, podał orła za niedościgły wzór wszystkim innym. Okszyc zakończenie swojego utworu na orła Jego Królewskiej Mości utrzymał w podobnej konwencji:

Niech was prawe Orły znamy,

A Kania niech myszy skubie.

Zadąwszy łeb w ogon dłubie,

Wy wzgórę latajcie66.

Za przykład karykatury orła można uznać inne ptaki drapieżne, jak choćby kanię (łac. milvus). Izydor z Sewilli pisał, że „nie imponuje ona ani siłą, ani lotem. Jest tak jakby »słabym ptakiem «, stąd ma pochodzić jej łac. nazwa mollis avis"67. Rej przedstawiał kanię jako tchórzliwego ptaka latającego nisko i uganiającego się za myszami. Jest to drapieżnik, który „zadąwszy łeb w ogon dłubie”, co stanowiło wyrazisty emblemat ludzkiej pychy i miłości własnej. Nasz XVI-wieczny znawca Mateusz Cygański w Myślistwie ptaszym zanotował, iż: „Nie wie na coć się zgodzić ma [ta kania], ale że szkodę czyni, tedy iey nie żal dostać"68.

64 Tamże, s. 83.

65 M. Rej, Wizerunk..., cz. I, s. 454.

66 Tegoż, Postylla..., cz. II, dz. cyt., list 2v.

67 Etymologies of Isidore of Seville, dz. cyt., s. 268.

68 M. Cygański, Myślistwo ptasze. Wydanie z 1584 roku oraz 1842 roku, objaśn. A. Waga, Warszawa 2014, s. 184. 
Jej brak przydatności szedł w parze - jak to często bywa- z pyszałkowatym charakterem. Kiedy bowiem dumnie stała „zadąwszy łeb”, nie była w stanie sięgnąć wzrokiem poza swój ogon. Rej niejednokrotnie w innych utworach przywoływał jej obraz jako przykład głupoty i próżności, ponieważ kania tylko: „[...] myszy skubie/ Zadąwszy łeb w ogon dłubie" ${ }^{69}$. Negatywna ocena jej natury zawarta była też w potocznym powiedzeniu; „wlec się kaniego”, po które Rej chętnie sięgał: „A ten to szlachetny sokoł narodu ludzkiego,/ Mogąc bujać wysoko, wlecze się kaniego"70.

Według bestiariuszowych przekazów, kania miała więc być lękliwa wśród wielkich, a odważna wśród maluczkich, dlatego najchętniej polowała na bezbronne pisklęta, ptactwo domowe i myszy. Hugon z Folieto porównał ją w Aviarium do ludzi słabych i rozpustnych, a swój wywód podsumował znaczącą pointą:

Oto w jaki sposób ptaki, które są pozbawione rozumu, ludzi doświadczonych i używających rozumu, pouczają przykładami przewrotnego postępowania ${ }^{71}$.

Zestawianie negatywnych cech drapieżnych ptaków, jakimi są kanie, z ideałem orła uświadamiało czytelnikowi, jak dalece nasze niedoskonałe zmysły mogą zniekształcić prawdziwy obraz rzeczywistości, myląc się często w swojej ocenie sytuacji. Bez wątpienia kania wykazywała brak zalet właściwych szlachetnym ptakom drapieżnym. Wprowadzenie motywu tchórzliwej kani jako przeciwieństwa króla ptaków w zakończeniu wiersza na orła Jego Królewskiej Mości miało swoją głęboką wymowę. Wszak „synowie orłowi”, a także ich podniebne siedlisko nie mieli sobie równych. Ostatecznie wyłoniła się z tego tekstu wizja Polski jako siedziby orła, strażnika ojczystego gniazda. Królewski ptak stanowił symbol potężnego chrześcijańskiego władcy pośród innych narodów, ale także duchowego przewodnika „stryjców”, tj. braci

70 Tegoż, Wizerunk..., cz. II, dz. cyt., s. 305.

71 Hugon z Folieto, Aviarium, dz. cyt., s. 139. 
szlachty. Ci ostatni powinni starać się dowieść swojego prawa do noszenia zaszczytnego miana „synów orłowych”. Swoistej wymowy dodaje fakt, iż Rej zamieścił ów utwór na samym początku tak religijnego dzieła, jakim była Postylla.

Z metaforą orła można spotkać się także w twórczości współczesnego Rejowi Marcina Bielskiego. Obydwaj nasi pisarze chętnie sięgali po topos orlego gniazda jako „ojczyzny szlachectwa duszy”, ale również państwa polskiego, którego godłem był właśnie ten królewski ptak. Bielski zarówno w Kronice wszytkiego świata, jak i Kronice polskiej przytoczył historię założenia pierwszej stolicy Polski przez Lecha:

[...] tamże założył miasto Gniezno i zamek nad Jeziory, a imie dał mu z wróżki Gniezno, iż tam widział pełno orłowych gniazd po drzewie. Ztądżę i na chorągwiach swych kazał kłaść orła białego za herb, a od tegoż czasu to królestwo polskie tego klejnotu używa ${ }^{72}$.

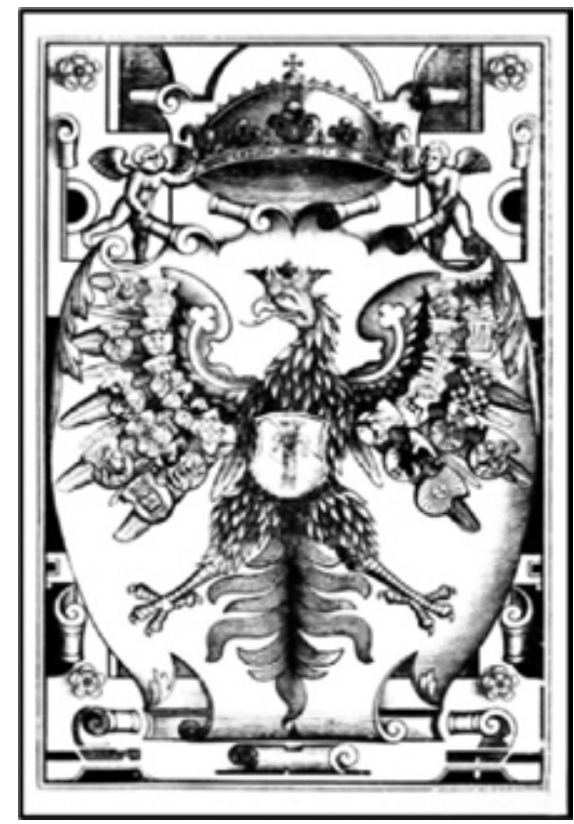

Orzeł, M. Siennik, Herbarz to jest ziół tutecznych, postronnych i zamorskich opisanie [...] (1568)

72 Kronika polska Marcina Bielskiego, t. 1, wyd. K. J. Turowski, Sanok 1856, s. 42 oraz M. Bielski, Kronika wszystkiego świata..., dz. cyt., list 339. 
W Kronice polskiej Bielski opisał również Kraków, gdzie zamieścił niezbędne informacje dotyczące sukcesji naszej państwowej potęgi. Stolicznemu gniazdu, potężnego podówczas mocarstwa - jak pisał - „przyszło do tego, że dziś z niemieckimi i włoskiemi przedniejszymi miasty może wielkością, dostatkiem i ochędóstwem zrównać się"73. Bielski pragnął podkreślić szlachetny charakter krakowskiego grodu i potęgę jego władcy.Wskazał na podobieństwo kształtu miejskich zabudowań zarówno do lutni, nieodłącznego atrybutu boskiej harmonii, jak również do orła - królewskiego ptaka:

Gdy na nie z góry zwierzynieckiej pojźrzy (bo z tamtąd najlepiej się mu przypatrzy), jest coś podobne do lutnie okrągłością swą, a Grodzka ulica i z zamkiem jest jako szyja u lutnie właśnie. Ma też coś podobnego do orła, którego głowę reprezentuje zamek, Grodzka ulica szyję, przedmieścia zasię około niego są jako skrzydła jakie ${ }^{74}$.

Nieprzypadkowo centralne miejsce herbu XVI-wiecznego Krakowa zajmował biały orzeł. Został on umieszczony w otwartych bramach grodu jako symbol zwycięstwa. Kategorie moralne i polityczne ucieleśnione przez króla ptaków okazały się ściśle ze sobą połączone. Symbol orła nobilitował dzieje stolicznego gniazda, a wraz z nimi całej Polski. We Wtórych Księgach Mojżeszowych, które zowa Exodus sam Bóg został porównany do orła, który niesie na skrzydłach naród wybrany do wyznaczonego celu (2 Ks. Mojż. 19, 4) $)^{75}$. W metaforze królewskiego ptaka połączyły się więc różne tradycje: biblijna z legendą rzymskiego imperium, dając asumpt do rozwoju potężnego państwa Jagiellońskiego jako siedziby ludzi sprawiedliwych i heroicznych. Orzeł uchodził za emblemat „ptaka niebieskiego”, który oznaczał zwycięską walkę sił dobra z mocami zła. Do tej tradycji żarliwie nawiązywał Mikołaj Rej w swojej twórczości. W Postylli Okszyc podjął wątek eucharystycznego komentarza św. Ambrożego do fragmentów Ewangelii (Mt. 24, 28

73 Kronika polska Marcina Bielskiego, t. 1, dz. cyt., s. 49.

74 Tamże, s. 49-50.

75 Zob. S. Kobielus, Bestiarium chrześcijańskie..., dz. cyt., s. 233 oraz Biblia Brzeska..., dz. cyt., s. 70. 
i Łk. 17,37$)^{76}$, dotyczących symboliki orła. Warto przyjrzeć się najpierw, w jaki sposób zinterpretował ten fragment sam autor Hexaemeronu:

Stałeś się szlachetnym orłem, odkąd zacząłeś dążyć do nieba, a gardzić ziemią. Szlachetne orły krążą wokół ołtarza, bo »gdzie ciało tam i orły« (Mt 24, 28; Łk. 17, 37). Ołtarz jest symbolem cała, na ołtarzu zaś spoczywa Ciało Chrystusa. Wy jesteście orłami odnowionymi przez obmycie z grzechów ${ }^{77}$.

Rej w Postylli wyłożył znaczenie tego passusu w podobnym duchu:

A Pan twój tu na cie mocno woła, nie wierz, a nie daj sie zwodzić. Albowiem pewnie wiedz, iż jedno tam będą wierni Orłowie jego. Gdzie on prawdziwie jest: a którzy się rozno rozlecą od niego, pewnie w głuchych lesiech świata tego nigdzie go nie najdą, ani sie go dopytają ${ }^{78}$.

Gdzie indziej dla odmiany podjął Rej metaforę „fałszywych orłów”, bo i takie często się zdarzały. Zastąpił je wyobrażeniem będącym przeciwieństwem życiodajnej energii, tj. obrazem „trującego plastra miodu”, który „póki w uściech poty słodko, a potym zasię w żołądku długie gryzienie a długie bolenie po nim bywa"79.

Symbolika orła zazwyczaj odnosiła się do walki dobra ze złem. Podobnie jak inne zwierzęta, także orzeł nie posiadał wyłącznie dodatniej wykładni alegorycznej. W przeciwieństwie jednak do innego królewskiego drapieżnika - lwa, ptak ten w rodzimych interpretacjach opatrywany był jedynie pozytywnymi konotacjami o religijnym charakterze ${ }^{80}$. Skoro orzeł tak mężnie walczył z diabelskim smokiem, to nadawał się jak nikt

76 Św. Ambroży, Wybór pism dogmatycznych, przeł. i oprac. L. Gładyszewski, Sz. Pieszczoch, Poznań 1970, s. 71 i nast.

77 Cyt. za: D. Forstner, dz. cyt., s. 241.

78 M. Rej, Postylla, cz. II, dz. cyt., list 261 r.

79 Tamże, list $261 \mathrm{r}$.

80 R. Kiersnowski, Symbol ptaka, dz. cyt., s. 107; zob. S. Kobielus, Biestiarium chrześcijańskie..., dz. cyt., s. 237. W sensie negatywnym postrzegali symbol orła m.in. „Klemens Aleksandryjski oraz Grzegorz Wielki, uważając tego ptaka za symbol zdradliwych duchów porywających dusze". Tamże. 
inny na strażnika prawdy, a co za tym idzie na opiekuna duszy ludzkiej. Niektórzy twórcy uznawali go także za atrybut św. Pawła Apostoła, gdyż w swoich wizjach został on cudownie jakby na potężnych skrzydłach uniesiony do trzeciego nieba $(2 \text { Kor } 12,2)^{81}$. Rej posłużył się także biblijnymi cytatami przy dawaniu rad, w jaki sposób cnotliwy człowiek winien się „strzec od wymyślaczów tego świata”82. Dobrą ilustrację takich zapobiegawczych praktyk można znaleźć w epigramacie z jego Źwierzyńca pt. Orzet na ostrożność (LXXX):

Orzeł, ten sobie bujno lata pod obłoki, Przepatrując, co broi marny świat szyroki.

Takżećby poważna myśl zawżdy bujać miała, Aby szkodliwe czasy wżdy przepatrywała.

Bo snadź nawiętszy rozum, gdy kto przyszłe rzeczy,

Rozmyślając roztropnie, zawżdy ma na pieczy;

Bo ty jedno, co zeszły, czynią nam ćwiczenie, Bychmy na to, co przyjść ma, wżdy mieli baczenie ${ }^{83}$.

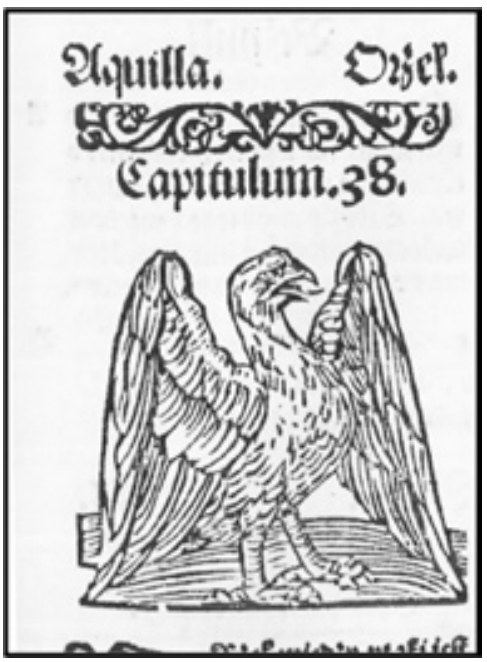

Orzeł z zielnika Falimirza, $O$ ziołach i mocy ich..., ( list17r.)

81 Tamże, s. 237.

82 M. Rej, Postylla, cz. II, dz. cyt., list 261r.

83 Tegoż, Źwierzyniec (1562), wyd. W. Bruchnalski, Kraków 1895, s. 246. 
Symboliczne znaczenie orła stało się dla Reja nie tylko synonimem cnót narodowych, klejnotem szlachectwa, które Bóg tylko „królom przydał"84, takich jak umiar, sprawiedliwość, wielkoduszność, hojność czy duchowa przemiana. Obraz tego królewskiego ptaka okazał się także skarbnicą wszystkiego tego, co kojarzyło się z najcenniejszymi zdolnościami umysłu ludzkiego. Działanie wyższego rozumu było w swej istocie - według św. Augustyna - ,poddaniem jednostki temu, co ją przekracza, i przylgnięciem myśli do źródła światła, które oświeca wszystkie nasze myśli" "85. Orzeł wpatrujący się w słońce, stał się więc boskim zaczynem duchowej przemiany człowieka cielesnego w odrodzoną postać człowieka wewnętrznego.

Bez wątpienia metafora „lotnego umysłu”, który szybuje nad poziomą rzeczywistością, stanowiła ulubiony motyw wszystkich dawnych encyklopedystów. Albert Wielki w De animalibus tłumaczył, dlaczego orzeł lata tak wysoko. Podobno powodował nim lęk, że lecące ponad nim ptaki, mogłyby go oskubać z piór lub zadziobać na śmierć. Dlatego też wznosił się najwyżej z nich wszystkich ${ }^{86}$. W średniowiecznej encyklopedii Imago mundi Honoriusz Augustodunensis posłużył się właśnie taką orlą perspektywą oglądu świata. Dostarczony przez niego opis uniwersum dokonany został niejako z pozycji unoszącego się wysoko nad ziemią królewskiego ptaka, który stopniowo zniżał swój lot. Przyniosło to poetycki efekt w postaci kontrastowych zestawień, polegający na dość szokującym konflikcie proporcji. Pierwotnie nieduże wzniesienia i doliny oglądane z góry, stały się w jego ujęciu małe niczym palec wędrowca, podczas gdy obraz człowieka stopniowo całkowicie je przesłonił ${ }^{87}$. Ten kompozycyjny i stylistyczny zabieg posłużył egzemplifikacji jednej z kluczowych prawd dawnego encyklopedyzmu. Świat został stworzony przez Boga dla człowieka, aby mu służyć. Model ten znakomicie ilustrował

84 Tegoż, Postylla, cz. II, dz. cyt., list $1 \mathrm{v}$.

85 É. Gilson, Wprowadzenie do nauki świętego Augustyna, przeł. Z. Jakimiak, Warszawa 1953 , s. 156.

86 Albertus Magnus, dz. cyt., vol. II, s. 1551.

87 E. Keen, Shifting horizons: The Medieval compilation of Knowledge as Mirror of a Changing World, [w:] Encyclopaedism from Antiquity to Renaissance, ed. J. Köning, G. Woolf, Cambridge 2013, s. 289. 
podstawową ideę dawnego encyklopedyzmu, w którym wszystkie elementy opisanej rzeczywistości były zaledwie pretekstem do zgłębienia tajemnicy ludzkiej natury.

Niezwykła zdolność do wysokiego lotu majestatycznego ptaka, jakim jest orzeł, sprzyjała filozoficznym spekulacjom odnośnie transcendentnych granic ludzkiego poznania. Sami encyklopedyści podsuwali możliwość boskiej pomocy przydanej ludziom w ciasnym wymiarze ziemskiej egzystencji. Warto zwrócić uwagę, że orły - już według pseudo-Dionizego Areopagity - pod wieloma względami wydawały się pokrewne anio$ł^{88}$. Rej w Apocalypsis również połączył te dwa symbole: Ale orzeł li Anjoł li, tedy to nam znamionuje opatrzność, wiadomość, i z dawna przejrzenie wszytkich rzeczy Pana naszego [...]"89. Inny z kolei encyklopedysta Bartłomiej Anglik w De proprietatibus rerum omówił właściwości chórów anielskich. Dowodził, że ostatni, dziewiąty chór istnieje jakby na „horyzoncie ziemskiego kręgu, tj. na granicy czasu i wieczności”"90. Figura orła zdawała się podsuwać zbliżony model epistemologiczny wypracowany przez św. Augustyna, który zapowiadał możliwość wyzwolenia się człowieka z przyrodzonych ziemskich ograniczeń. Ważne było, żeby w dążeniu do wieczności, ani na chwilę nie stracić z pola widzenia doczesnego widnokręgu. Prastara poetycka metafora intelektualnych wzlotów - tak dobrze znana zarówno z pism Platona, jak i poezji Horacego - niosła wraz z sobą efekt duchowej transformacji. Ów mistyczny stan w niezapomniany sposób przedstawił Boecjusz w traktacie $O$ pocieszeniu, jakie daje filozofia:

Mam skrzydła mocne, świetne do lotu,

Mogą mnie wznieść na grzbiet nieba.

88 Pseudo-Dionizy Areopagita, Hierarchia niebiańska, [w:] tenże, Pisma teologiczne, t. 2, przeł. M. Dzielska, przedm. T. Stępień, Kraków 1999, s. 172; zob. S. Kobielus, Bestiarium chrześcijańskie..., s. 235.

89 M. Rej, Apocalypsis, dz. cyt., list 75v.

90 E. Keen, Shifting horizons..., dz. cyt., s. 293. Izydor potwierdzał obecność aniołów jako mieszkańców podksiężycowego świata, pełniących rolę nadzorców, chociaż istniejących poza granicami naszego wzroku. Tamże, s. 282. 
Gdy tylko umysł się w nie ubierze,

Z wysoka spojrzy na przykrą mu ziemię ${ }^{91}$.

Czy inspirował się (XXIV) pieśnią Horacego? Bardzo możliwe. Faktem jest, że słowa te powrócą echem w twórczości uczonego Palingeniusza w Zodiacus vitae, gdzie bez trudu rozpoznać można tę samą przenośnię porywów królewskiego ducha:

I wznieść się lekkim lotem na wyżyny nieba.

Skąd często mam w zwyczaju przyglądać się ziemi,

Podziwiając, jak mała i nędzna się zdaje,

Wisi jak małe jabłko pośrodku powietrza (IV, 836-839)92.

Skoro Wizerunk Reja był inspirowany Zodiakiem życia Palingeniusza, to jego partie opisowe, które starały się dowieść, że mądrość „uwalnia z ziemskich uczuć i przychyla nieba"93, pozostawały w ścisłym związku z metaforyką „lotu orła”:

Wszystko tego ten człowiek rozumem dosięgnął,

By sie tam jako ptaszek pod niebem wylągnął

Jako sie toczy niebo, jako ziemia pływa

I jaka pod nią sprawa i na spodku bywa,

[...] Wszytkę ziemię i niebo szalonym łbem skreślił,

Nie masz tak nic trudnego, czego nie wymyślił94.

Doprawdy intrygująca jest ta nieskrywana fascynacja orlim fenomenem u naszych tak praktycznych przecież pisarzy. Nie wynikała ona raczej z ich pasji myśliwskiej, ponieważ orzeł nie pozostawał u nas ptakiem

91 A. M. S. Boecjusz, O pocieszeniu, jakie daje filozofia, przeł. i oprac. G. Kurylewicz i M. Antczak, przedm. A. Kijewska, Kęty 2006, s. 89.

92 Palingeniusz (Marcellus Palingenius Stellatus), Zodiak życia, przeł. i oprac. U. Bednarz, wstęp U. Bednarz i J. Sokolski, Wrocław 2015, s. 171-172.

93 Tamże, s. 198.

94 M. Rej, Wizerunk..., dz. cyt., s. 85. 
używanym w sokolnictwie. Pośród różnych jego odmian jedynie birkut był zaprawiony do łowów i kupowany przez szlachtę od Tatarów. Brakuje informacji na temat polowania z orłem w dawnej Polsce ${ }^{95}$. Mateusz Cygański w Myślistwie ptaszym zaledwie napomknął o próbach układania orła do łowów po to, by ostatecznie odradzić wszystkim te praktyki ${ }^{96}$. Zresztą poglądy te chyba powtórzył za Ksiegami o gospodarstwie Crescentyna ${ }^{97}$. Niezwykła uroda orła także nie wydawała się najistotniejsza, chociaż w bestiariuszowych deskrypcjach eksponowany jest jego groźny i majestatyczny wygląd. Uczone komentarze podkreślały znaczenie orła w wymiarze zarówno ziemskiej, jak i boskiej potęgi ${ }^{98}$. Utwory Reja i Bielskiego pozostawały w obrębie tej tradycyjnej symboliki, chociaż warto zwrócić uwagę na jeszcze jeden wspólny element w ich kreacji świata. Jest on tak oczywisty, że prawie niedostrzegalny.

Wspomniany szczegół dotyczy wizerunku samego orła, który jest widoczny we wszystkich przytoczonych powyżej cytatach dzieł naszych pisarzy. Warto zatem bliżej przyjrzeć się obrazowi tego ptaka, jaki wyłania się w świadomości odbiorcy. Mimo opinii, że Rej był zwolennikiem empirycznej obserwacji natury, wyraźnie widać, jak w jego poetyckich opisach na plan pierwszy wysuwa się przede wszystkim idea samego orła. Przedstawienia faunistyczne, zostały u niego więc wsparte nie tyle na obserwacji, co na szczególnym rodzaju erudycji i „pamięci wizualnej" 99 . Chodziło o ukazanie w kreacji zwierzęcia jakiejś najbardziej charakterystycznej właściwości, która miała złożyć się na niezbędną wiedzę o nim ${ }^{100}$. Z bestiariuszowych komentarzy wynikało jasno, że tym, co

95 K. hr. Wodzicki, O sokolnictwie i ptakach myśliwskich, Warszawa 1858, s. 17; zob. też W. Dynak, Łowy, łowcy i zwierzyna w przysłowiach polskich, Wrocław 1993, s. 297-298.

96 M. Cygański, dz. cyt., s. 101-102.

97 P. de Crescentiis, Liber ruralium commodorum/, pol. Ksiegi o gospodarstwie i o opatrzeniu rozmnożenia rozlicznych pożytków każdemu stanowi potrzebne, przeł. A. Glaber?, Kraków: Helena Florianowa, 1549, s. 620.

98 Grzegorz Wielki, dz. cyt., s. 329.

99 F. A. Yates, Sztuka pamięci, przeł. W. Radwański, posłowie L. Szczucki, Warszawa 1977, s. 33.

100 W. N. West, Theatres and Encyclopedias in Early Modern Europe, Cambridge 2002, s. 101 i nast. 
wyróżniało orła wśród innych zwierząt, był jego niezwykle przenikliwy wzrok. Jednak encyklopedyczna tradycja przechowała przez kolejne stulecia coś więcej niż tylko przekonanie o bystrości orlego spojrzenia.

Wyobrażenie orła stało się zatem tożsame ze wzrokiem, uchodzącym za najdoskonalszy narząd ludzkiego poznania. W żadnej innej części ciała - według Historii naturalnej Pliniusza Starszego - „nie masz większej wskazówki umysłu [...]. Zaiste w oczach mieszka dusza [...], duszą też widzimy, duszą rozważamy [...]. Organ ten tak doskonałą ma właściwość zwierciadła, iż owa tak mała źrenica cały wizerunek człowieka oddaje"101. Podobnie Albert Wielki w De animalibus zwrócił uwagę na „świecące oczy [orła], które są żółte ponad wszelką miarę, do tego stopnia, że biel oka przedstawia prawie topaz a źrenica ma wygląd bardzo przejrzystego czarnego szafiru [...]. Obszar jego brwi to kostny grzbiet wyrastający nieco ponad oczy, tak, że w cieniu brwi wydają się koncentrować wizję"102. Taka „orla perspektywa oglądu”, dzięki której wpatrywano się w słońce prawdy, oznaczała całkowite poddanie się działaniu kontemplacji, co widoczne było na wszystkich poziomach życia duchowego ${ }^{103}$. W języku łacińskim pojęcie speculum pochodziło od specere przypatrywać się i oznaczało lustro, obraz czy podobiznę ${ }^{104}$. Tymczasem poznanie za pośrednictwem zwierciadła (per speculum) dokonywało się poprzez studia nad naturą (per creaturas), co prowadzić miało człowieka, niejako po drabinie bytów, stopniowo od poznania rzeczy widzialnych, niewidzialnych istot aż do samego poznania Boga ${ }^{105}$.

Dla Reja zwierciadło to rodzaj obrazowego przykładu ${ }^{106}$. Podobnie dla Bielskiego egzemplaryczne historie były „nauką żywota jako obrazy albo świece sprawam ludzkim w umyśle świecąc, ostrzegając nas od przygód

101 Zob. K. Pliniusza Starszego Historyi naturalnej ksiag XXXVII, t. X, przeł. J. Łukaszewicz, wyd. E. Raczyński, Poznań 1845, s. 261, 263 i 265 (ks. XI).

102 Albertus Magnus, dz. cyt., vol. II, s. 1549.

103 É. Gilson, Wprowadzenie do nauki św. Augustyna, przeł. Z. Jakimiak, Warszawa 1955, s. 154.

104 Stownik łacińsko-polski, t. V, pod red. M. Plezi, Warszawa 1999, s. 192. Rej w Wizerunku..., dz. cyt., s. 513 - opisuje zmysł wzroku.

105 Tamże, s. 175.

106 M. Rej, Postylla, cz. II, dz. cyt., list 350v. 
złych, a ku dobrym przykładnie wiodąc [...]"107. W tym wypadku umiejętność ujrzenia, jak w zwierciadle (in speculo) ${ }^{108}$, czyli poznania w obrazach stworzenia (in creaturis), składała się na sztukę dostrzegania w świecie Boga i śladów Jego działania"109. W Żywocie człowieka poczciwego Okszyc dowodził, iż czerpane z przyrody przykłady stanowią najlepszą lekcję roztropnego działania, chroniąc człowieka przed licznymi niebezpieczeństwami:

Ale gdy weźmiesz stałą a stateczną myśl przed sie, a opaszesz sie nadzieją nieomylną w każdej przygodzie swej, a poźrzysz w rozum swój, jako we źwierciadło, a upatrzysz tam wszytki niebezpieczności a odmienności świata tego, a upatrzysz to w rozmyślaniu swoim, iż żaden na świecie, by też nazacniejszy i naświętszy, bez przygód nigdy być nie mógł, boć dla tego Pan Bóg oczy wyniosłe dał, abyś nie tylko sobie na pięty patrzył, ale iżbyś $i$ upatrował i rozmyślał sobie przyszłe i przeminęłe rzeczy ${ }^{110}$.

Jednakże oczy pozbawione światła prawdy - jak pisał Okszyc - „ślepemi [sie] zowie, które jedno dziwują się świętemu Bóstwu jego, a są jako bielmem zakażone, iż jedno tylko blask widzą, a nie wiedzą, co im świeci [...]"111. Stąd ludzi pozbawionych blasku wiedzy porównywał on do nocnych ptaków:

Tak tępość zaślepiona narodu ludzkiego,

Że w niej nie używamy zwyczaju orlego,

Który sie w sobie kocha, kiedy patrzy w słońce;

Ale puhacz, ni sowa nigdy tego nie chce ${ }^{112}$.

Zgubna okazuje się także nadmierna ciekawość świata, kojarząca się naszym pisarzom z ludźmi, którzy za bardzo pragnęli wniknąć w bo-

107 M. Bielski, Kronika wszytkiego świata..., dz. cyt., list 333v.

108 M. Rej, Postylla, cz. II, dz. cyt., list 75v.

109 Tamże.

110 Tegoż, Żywot człowieka poczciwego, t. 2, dz. cyt., s. 82.

111 Tamże, list 203v.

112 Tegoż, Wizerunk..., cz. II, dz. cyt., s. 429. 
skie tajniki bytu. Szkodliwość takich zabiegów była równie zgubna, jak w poprzednim wypadku, przed czym przestrzegał Rej w Wizerunku:

Więc drugi nad księgami rzkomo przepieruje,

Chce sokoły zalecieć, więc rozum szychtuje.

Ale podobno rychlej pojdziemy sowiego ${ }^{113}$.

Trudno doprawdy o lepszy ogląd świata dokonany z pozycji obserwatora, jakim jest - zapośredniczona przez figurę orła - możliwość „z nieba cudnego wyjrzenia"114. Można chyba powiedzieć, że motyw ten tworzył ogniwo łączące statyczną przestrzeń encyklopedycznej wiedzy z poszczególnymi jej kontekstami, w które raz po raz wkraczał czytelnik. Bez wątpienia twórczość Reja i Bielskiego - mimo jej dyskursywnego charakteru - miała charakter wizualny. Dzieła naszych pisarzy skupiały się wokół egzemplarycznych obrazów, wyraźnie zmierzając w kierunku spektakularnego ideału wizji jako wiedzy autorytatywnej. Ich utwory pełne są zwrotów w rodzaju: „albowiem, kto się chce przypatrzyć”, „patrzaj”, „weźrzyj”, „bo patrz”, „albowiem patrzaj albo czytaj”, „czy „słuchaj i patrzaj”. Nagrodą za ten uważny namysł nad sobą i światem dla każdego „dobrego towarzysza k`woli” była zbawienna nagroda w postaci:

[...] mądrości, [która] jest coś dziwnego, coś poważnego, a prosto jest z nieba dar Boży, która nigdy ponuro w niebo nie patrzy, jako gęś skubiąc trawę, ale buja sobie w rozmyśle poczciwego człowieka, jako orzeł, zawżdy z wysoka upatrując a każdy czas uważając, gdzie co przystojnie do czego przystosować może, a na to, co może na wszem ozdobić człowieka poćciwego ${ }^{115}$.

Warto pamiętać, że uporządkowana struktura encyklopedycznej rzeczywistości pełniła kiedyś rolę czegoś w rodzaju modelowego „przewodnika zbawienia”, który dzisiaj można nazwać vademecum prawdziwego

113 Tamże, s. 402.

114 Tegoż, Postylla, cz. II, dz. cyt., list 222.

115 Tegoż, Żywot człowieka poczciwego..., t. 2, dz. cyt., s. 64, zob. też t. 1, dz. cyt., s. 64 . 
człowieczeństwa ${ }^{116}$. Skorygowany i poprawiony obraz kondycji ludzkiej, jaki pojawił się w utworach Reja i Bielskiego, złożył się na zwierciadlane odbicie doskonałości świata natury, będącej jakby rodzajem poręcznej mapy, wiodącej do utraconego królestwa niebieskiego.

\section{Bibliografia}

Albertus Magnus, On Animals. A Medieval Summa Zoologica, vol. II, transl. and annotated by Kenneth F. Kitchell Jr. \& Irven Michael Resnick, London 1999.

Ambroży Św., Hexaemeron, przeł. Władysław Szołdrski, opatrzył wstępem Andrzej Bogucki, oprac. Wincenty Myszor, Warszawa 1969.

Ambroży Św., Wybór pism dogmatycznych, przeł. i oprac. Ludwik Gładyszewski, Szczepan Pieszczoch, Poznań 1970.

Ambroży Św., Wybór pism. O pokucie. O ucieczce od tego świata. O dobrach przynoszonych przez śmierć, przeł. Władysław Szołdrski, wstęp Cyryl Andrzej Guryn, oprac. Cyryl Andrzej Guryn i Emil Stanula, Warszawa 1971.

Arystoteles, Zoologia (Historia animalium), przeł., wstępem, komentarzem i skorowidzem opatrzył Paweł Siwek, Warszawa 1982.

Biblia święta to jest Księgi Starego i Nowego Zakonu własnie z żydowskiego, greckiego i łacińskiego nowo na polski z pilnością i wiernie wyłożone. Transkrypcję oraz kolacjonowanie tekstu Biblii Brzeskiej [Brześć 1563] [...], edycja Peter Krolikowski, Clifton, New Jersey-Kraków 2003.

Bielski Marcin, Kronika to jest historia Świata na sześć wieków a cztery monarchie rozdzielona z rozmaitych historyków tak w świętym piśmie krześcijańskim, żydowskim jako i pogańskim wybierana i na polski język wypisana dostateczniej niż pierwej z przydanim wiele rzeczy nowych: Od początku świata aż do tego roku, który się pisze 1564. Figurami ochędożnym i własnymi, przedruk metodą fotooffsetową, Warszawa 1976.

116 E. Keen, Shifting horizons..., dz. cyt., s. 277. 
Boecjusz Anicjusz Manliusz Sewerynus, O pocieszeniu, jakie daje filozofia, przeł. i oprac. Gabriela Kurylewicz i Mikołaj Antczak, przedm. Agnieszka Kijewska, Kęty 2006.

Crescentiis Pietro de, Liber ruralium commodorum, / pol. Księgi o gospodarstwie i o opatrzeniu rozmnożenia rozlicznych pożytków każdemu stanowi potrzebne, przeł. Andrzej Glaber?, Kraków: Helena Florianowa, 1549.

Cygański Mateusz, Myślistwo ptasze. Wydanie z 1584 roku oraz 1842 roku, objaśn. Antoni Waga, Warszawa 2014.

Dynak Władysław, Łowy, łowcy i zwierzyna w przysłowiach polskich, Wrocław 1993.

Erazm z Rotterdamu, Adagia (wybór), przeł. i oprac. Maria Cytowska, BN II, nr 172, Wrocław 1973.

Etymologies of Isidore of Seville, transl. Stephen A. Barney, W. J. Lewis, J. A. Beach, Oliver Berghof, New York 2006.

Falimirz Stefan, O ziołach i mocy ich [...], wyd. Florian Ungler, Kraków 1534.

Fizjolog, przeł. wstęp i przyp. Katarzyna Jażdżewska, Warszawa 2003.

Fleming J. V., Natura Lachrymosa, [w:] Man and Nature in the Middle Ages, ed. by Susan J. Ridyard and Robert G. Benson, Sewanee 1995.

Gilson Étienne, Wprowadzenie do nauki św. Augustyna, przeł. Zygmunt Jakimiak, Warszawa 1955.

Gilson Étienne, Wprowadzenie do nauki świętego Augustyna, przeł. Zygmunt Jakimiak, Warszawa 1953.

Gloger Zygmunt, Encyklopedia staropolska ilustrowana, t. IV, wstęp Julian Krzyżanowski, Warszawa 1989.

Grzegorz Św., Moralia. Komentarz do Księgi Hioba. T. 6: Księgi XXVIII-XXXII, red. nauk. Leon Nieścior, przeł. Adam Wilczyński, oprac. i korekta przekł. Elwira Buszewicz, Kraków 2016.

Guriewicz Aron, Kategorie kultury średniowiecznej, przeł. Józef Dancygier, Warszawa 1976.

Hugon z Folieto, Aviarium, [w:] Fizjologi i Aviarium. Średniowieczne traktaty o symbolice zwierząt, red. Elżbieta Przybył, przeł. i oprac. Stanisław Kobielus, Kraków 2005.

Impelluso Lucia, Natura i jej symbole. Rośliny i zwierzęta, przeł. Hanna Cieśla, Warszawa 2006.

Iwaszkiewicz Bożena, Problematyka symboliki motywu orła w sztuce wczesnochrześcijańskiej, „Roczniki Teologiczno-Kanoniczne” 1974, t. XXI, z. 4. 
K. Pliniusza Starszego Historyi naturalnej ksiąg XXXVII, t. X, przeł. Józef Łukaszewicz, wyd. Edward Raczyński, Poznań 1845.

Keen Elizabeth, Shifting horizons: The Medieval compilation of Knowledge as Mirror of a Changing World, [w:] Encyclopaedism from Antiquity to Renaissance, ed. Jason Köning, Greg Woolf, Cambridge 2013.

Kiersnowski Ryszard, Symbol ptaka, [w:] Imagines Potestatis. Rytuały, symbole i konteksty fabularne władzy zwierzchniej. Polska X-XV w., pod red. Jacka Banaszkiewicza, Warszawa 1994.

Kobielus Stanisław, Bestiarium chrześcijańskie. Zwierzęta w symbolice i interpretacji. Starożytność i średniowiecze, Kraków 2002.

Kobielus Stanisław, Bestiarium chrześcijańskie. Zwierzęta w symbolice i interpretacji. Starożytność i średniowiecze, Warszawa 2002.

Kronika polska Marcina Bielskiego, t. 1, wyd. Kazimierz Józef Turowski, Sanok 1856.

Nowicka-Jeżowa Alina, Barok polski między Europą i Sarmacją. Cz. I: Profile i zarysy całości, Warszawa 2009-2011.

Orygenes, Homilie o Księgach Rodzaju, Wyjścia, Kapłańskiej, przeł. i oprac. Stanisław Kalinkowski, wstęp Emil Stanula, Warszawa 1984.

Palingeniusz (Marcellus Palingenius Stellatus), Zodiak życia, przeł. i oprac. Urszula Bednarz, wstęp Urszula Bednarz i Jacek Sokolski, Wrocław 2015.

Parent Jean-Marie, La doctrine de la création dans I 'école de Chartres, Paris-Ottawa 1938.

Pseudo-Dionizy Areopagita, Hierarchia niebiańska, [w:] Pseudo-Dionizy Areopagita, Pisma teologiczne, t. 2, przeł. Maria Dzielska, przedm. Tomasz Stępień, Kraków 1999.

Rej Mikołaj, Apocalypsis, pod red. Wojciecha Kriegseisena, oprac. Marta M. Kacprzak, Sebastian Kawczyński, Janusz Maciuszko, Izabela Winiarska, Warszawa 2005.

Rej Mikołaj, Postylla, cz. II, (nauk. opieka nad fototypią Władysław Floryan), red. Maria Renata Mayenowa, Bibl. Pisarzów Polskich ser. B, nr 14, Wrocław 1965.

Rej Mikołaj, Psalterz Dawidow / ktory snadz iest prawy fundament / wssytkiego pisma krzesćyjańskiego / teraz nowo prawie na Polski ięzyk przełożon [...], [Kraków, Maciej Szarfenberg? (ok. 1546)].

Rej Mikołaj, Wizerunk własny żywota człowieka poczciwego. Cz. I: Fototypia i transkrypcja tekstu, oprac. Władysław Kuraszkiewicz, Wrocław 1971. 
Rej Mikołaj, Źwierzyniec (1562), wyd. Wilhelm Bruchnalski, Kraków 1895.

Rey z Nagłowic Mikołaj, Żywot człowieka poczciwego, [w:] Mikołaj Rej, Źwierciadło albo kształt, w którym każdy stan snadnie sie może swym sprawam, jako we źwierciedle, przypatrzyć, t. 1-2, wyd. Jan Czubek i Jan Łoś, wstęp Ignacy Chrzanowski, Kraków 1914.

Siennik Marcin, Herbarz to jest ziół tutecznych, postronnych i zamorskich opisanie [...], Kraków (drukarnia Szarffenberga) 1568.

Słownik łacińsko-polski, t. V, pod red. Mariana Plezi, Warszawa 1999.

West William N., Theatres and Encyclopedias in Early Modern Europe, Cambridge 2002.

Wildiers Norbert Max, Obraz świata a teologia. Od średniowiecza do dzisiaj, przeł. Jan Doktór, Warszawa 1985.

Wodzicki Kazimierz hr., O sokolnictwie i ptakach myśliwskich, Warszawa 1858.

Yates Frances Amelia, Sztuka pamięci, przeł. Witold Radwański, posłowie Lech Szczucki, Warszawa 1977. 